\title{
Agôn
}

9| 2021

Rater

\section{INFERNO: Catastrophically Queer}

\section{Marcus Bell}

\section{(2) OpenEdition}

Journals

Electronic version

URL: https://journals.openedition.org/agon/8829

DOI: 10.4000/agon.8829

ISSN: 1961-8581

\section{Publisher}

Association Agôn

\section{Electronic reference}

Marcus Bell, "INFERNO: Catastrophically Queer", Agôn [Online], 9 | 2021, Online since 22 October 2021, connection on 17 January 2022. URL: http://journals.openedition.org/agon/8829 ; DOI: https://doi.org/ 10.4000/agon.8829

This text was automatically generated on 17 January 2022.

Association Agôn et les auteurs des articles 


\title{
INFERNO: Catastrophically Queer
}

\author{
Marcus Bell
}

1 Being queer means that you engage with failure on an almost daily basis, as a practice and an outcome; however, when success is measured by normative markers failure is not the end for queer actors. At INFERNO, failure played out as a modality - a type of expression, experience, a way of discussing a possibility or set of possibilities - within the queer rave's serendipitous network of deep affective relations. INFERNO is queer not only because it was run by and for queers but - because it queered public place, specifically the Institute of Contemporary Art (ICA, London), and the experience of inhabiting it. INFERNO ( $31^{\text {st }}$ January, 2020) presented a system of different performance events, providing participants with opportunities to not only witness but also to generate performance. And in this way INFERNO echoed, capaciously, participatory live art practices which have a long history in intersectional Black, Feminist, Crip, and Queer of Colour art and protest ${ }^{1}$. At the rave we were all invited to perform together and to generate alternative ways of becoming-with. Considering failure as one of those other ways, this essay takes seriously the questions INFERNO asked: what if we did burn it all down, what world would be possible after the end of Man, and how can we as queers celebrate each other, our practices of seeing, making, and emerging together ${ }^{2}$ ? I wager that failure attenuates listening and feeling differently.

In this reflection on the ICA INFERNO I ask, particularly, what is at stake in this constellation of failure, performance, and rave. I recall the erotic moving-image, liveart, and especially collective performance making between bodies en commun. I attempt to gather the traces of queer coalitional performance that spread throughout and took over the ICA on the dance floor, in the bathrooms, film screenings, and corridors. There, in the space opened up by INFERNO's curators DJ Lewis G. Burton and producer Sebastian Bartz, I examine Nick Finegan's 'Theseus on the Heap's' (2019), a hellish collage of ancient Greek myth and tragedy. I put forward the following thesis. By performing failure as a modality, the performers explored a tension between the failure of structures - grounded in/through/with racist colonialism - and their reemergance ${ }^{4}$. I observe that this double movement of failure and recuperation occurs under the conditions of a rave that does stage the end of humanity, but also note that 'Theseus on the Heap' conjured up the props, equipment, and tools of settler colonial 
oppression. INFERNO then explores the potential for the failure of the category of 'human' in a queer way and works for alternative futures from which multispecies assemblages may emerge ${ }^{5}$. But this process of refusal is not an easy one nor is it straightforwardly played out at INFERNO, as this line of flight remained in conversation with the systems of oppression it sought to disarticulate.

\section{You okay hun?}

3 What is there to say about this notion of queer failure? Jack Halberstam tells us that rubbing up against success but failing to attain it is a particularly queer feeling. In The Queer Art of Failure (2011) Halberstam disrupts the category of success, as nominally understood, by looking at moments for queer folk which 'present losing not as a final point but as a productive position ${ }^{6}$. This provocation echoes other queer studies centred on or around the question of failure in relation to notions of success and hope. Examples which resonate here may include Heather Love's Feeling Backwards (2007), Kadji Amin's Disturbing Attachments (2017), and José Esteban Muñoz's sustained investigation into queer utopias and their dialogue with failure in art and performance ${ }^{7}$. Settling Halberstam alongside Love, Amin, and Muñoz encourages us to read success not as a dominant marker of either a life worth lived, or a day worth endured. Instead, by attending to the emphasis they place on recuperating and vivifying the experience of queer failure we can think differently. Here we might see moments of failure as sites, imbricated within complex affective and action-orientated systems, which offer queers, offers us, radical potential for doing things differently. This alterity, which if it is also anti-racist in nature we might call a 'waywardness' after Saidiya Hartman, offers an alternative model for producing knowledge, and a queer technology for 'doing' the self'.

This would mean that queer gestures thrown against productivity, and the organised discontinuities of capital, made (un)intentionally against success become refusals of the model of progress (as Halberstam lays out) but do not have to lead to a kind of 'No Future' position'. Because, these gestures can also proposition an elsewhere they suggest the possibility for transport out of the bad feelings associated with failure and into something sweeter ${ }^{10}$. However, this escape from failure is not easily given, nor is it guaranteed. To understand this tricky migration we might situate Love, Amin, Halberstam and Muñoz within the networks of queer, BIPOC, and crip performers, theorist, activists, and artists making interventions in theory and practice; this would put them amongst folks who make explicit gestures towards overturning late capitalist models of success. Such an act would bring into field performers, activists, and writers: Dionne Brand, Sadiya Hartman, Tina Campt, Johanna Hedva, and Alison Kafer vel sim ${ }^{11}$. It might also allow other queer figures who refuse academic citational practice to become visible and audible, to vibrate at a higher frequency ${ }^{12}$ within this constellation. We might hear the drag queens who used to work nights in our local bars, agitate with the non-neuronormative, disabled, queer performance artists who used to do endurance based live art in that house that held raves. We might think about and with the queer folk in all forms of embodiment who took on myriad modalities of becoming, who use to sing, dance, yell, cry, caress, fuck and form networks of care in nightclubs, warehouses, in back rooms, and in kitchens, from their beds and in their fantasies. We 
might become with this vibrant assemblage of organs, technologies, prostheses, sounds, smells, ideas, feelings, and wants, hopes and traumas.

This expanded framework follows the lines of thought opened by Halberstam, Love, Amin, and Muñoz. And by listening and thinking with them we might develop a drive to oppositionally re-orient failure in relation to success, to celebrate the former over the latter. I think we should treat this move with a great deal of care - those writers are asking us to think with a great deal of care - because an intervention that merely switches success and failure might well lead us to an inverted view of the same problem. Because this reorientation, that places failure over success, could be accomplished without there being systemic change. So, instead I wager - by plugging the into three further systems-machines-coalitions: Queer raves, Critical Ancient World Studies and Theatre and Performance - that a mere reorientation of success and failure is not enough to think more equitably about the future ${ }^{13}$. Alongside this, the fact remains that the reorientation model does not provide us with a hermeneutic capable of vivifying the assemblage of material, technological, ideational, social and performative parameters that are rendered during queer performance at the rave. So instead, I want to think about failure as a mode in queer performance and to reach for the spaces (affective, ontological and epistemological) that are beyond the boundaries of the failure-success-capital triad. As in the rave - a complex space for affect, erotics, and play - I want to think about failure without obscuring the negative emotions and joyful potentials associated with it. So, I also want to render some of failures shame, anxiety, sadness, and disappointment.

6 Methodologically, I am reflecting on the traces that remain in the body from the rave. Taking my queue from embodied knowledge studies and the theorisations of Julietta Singh, T. M. Campt, and Rebecca Schneider ${ }^{14}$, I want to deemphasis my positionality as a sovereign subject, a stable singular human body in space. This is not to leave behind the privilege of my white economic migrant status, the way I am often (mis-)read as a cis-gendered man. It is instead to turn up the volume of listening on the inarticulate traces (Julietta Singh) and move to think about the lower frequency, body vibrations shared by folks in resistance to systems of oppression (T. M. Campt). Methodologically, this is an attempt to dematerialised the upper and lower limits of the stable body, to blur with the other bodies, (non)human agents, objects, materials, and gestures at the rave.

\section{Flaming queers}

7 INFERNO was organised by performance artist and DJ Lewis G. Burton and producer and musician Sebastian Bartz under their DJ alter-ego Venice Calypso. The event was hosted in the ICA and took place on the night that the UK formally left the European Union this event has of course reverberated, repeated on us, with the UK agreeing a separation deal a year later on $1^{\text {st }}$ Januray 2021. This ideological, first, 'formal' leaving incurred a social choreography of nationalistic mourning and celebration which the second did not. This first leaving was pre-pandemic and so if you had walked down the Strand in London you would have seen the traffic was backed up, Union Flags and St George's Crosses were posted along the road. In the queue, you would have heard cars full of Brexit supporters who jeered and honked their horns at the queers gathering. Those queers, we, huddled around each other for support. I remember lighting a 
cigarette with a stranger as we waited to head inside, to dance to the music, and feel the heat. We half-knew what we were expecting. As, in the words of the organisers, 'INFERNO marries the camp with the underground, pop with techno, and the very good with the very bad $^{15}$. However, INFERNO had never taken place in a venue quite like the ICA and the combination of this new setting and the surrounding tensions between us and the nationalistic cries for sovereignty created a feeling of apprehension. Something was ending and something else about to start.

\section{Strategy drawing of the ICA floorplan}

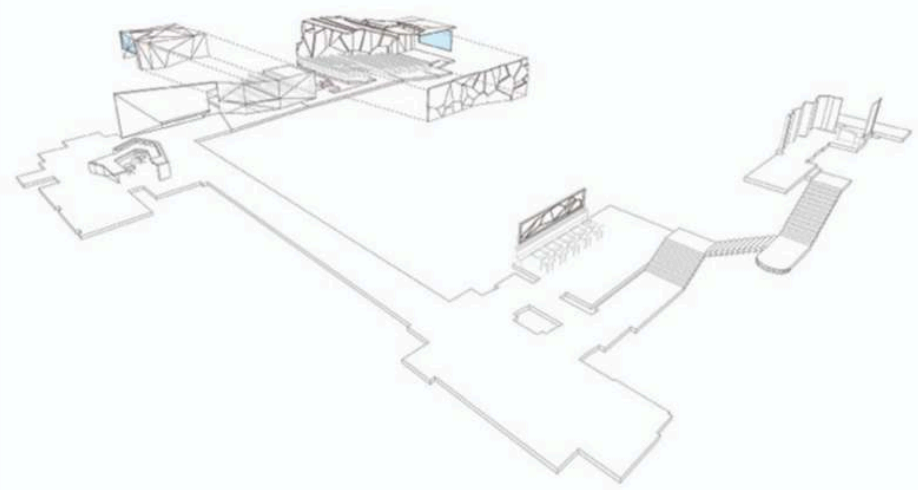

Copyright: Architects: Mueller Kneer Associates / Olaf Kneer, Marianne Mueller. Team: Olaf Kneer, Marianne Mueller, Sven Peiffer, Kok Loong Wong

8 Some very brief historical and contextual data: INFERNO developed over five years in and out of arts spaces in London, Paris, and Europe. When I first attended it was at the Yard theatre in Hackney Wick, a space it occupied for a long run. As well as providing an opportunity for queer art, performance, dance and music, INFERNO was becoming a community space. Moving from its North/East London roots, INFERNO at the ICA specifically commissioned Nick Finegan, Sweatmother, and Karl Murphy to make work for the night. Additionally, there were curated erotic and exploratory queer short films screening in the ICA's cinemas. I've included the map of the space above. You'll see that the stark lines of the plot lay against an open, empty, white background. This betrays the gallery. If you were to visit, you'd find instead that it is a close, grey, basement located on the river, amongst the soaring imperial stone of the mall; you'd find it next to Trafalgar square and the symbolic seats of parliament, down the road from Buckingham palace. In short, the ICA is nestled among the big hitters of a touristic central-London skyline, it is tucked in the armpit of a network of colonial monuments.

The entryway to the ICA can be located at the top left of the image. The bookstore, just to the right of those double doors has long been a hit amongst queers for its collection of art, theory, and pornographic material. A long walkway moves down towards a bar and cafe. What is not included in this image are the gallery spaces. A sunken pit opens up to the left of the walkway where instillations are set up. That night it lay dormant, empty, and if I remember correctly, cordoned off. All the way to the right should be a great large box where some of the performances that night took place. 
10 INFERNO sent vibrations through the space in a different key. For example, the bar, at the end of the walkway, became a liminal space of queer contact before, during and after the performances. Here we cruised, found, embraced one another, and expanded the affective networks we entered the ICA with that night. We queued here as well, to break our way into the cavernous room that hosted the performances. And we pooled back at this bar on our way out of that room. It became a space for moving in/out and a place of traces that were physically marked in both space and time.

11 Another way of putting this is, INFERNO modulated the art/gallery space to both generate and reveal its non-normative erotic potentials. It wasn't that no queers had ever locked eyes over a copy of a carefully held text in that bookshop, or cruised each other on the way into the cinema or toilets. But that night, those fragile caresses, bruised longings, and the sparks of many potential futures: erotic, care driven, political, aesthetic, creative were amplified. Lewis G. Burton described both this spacegenre modulation and the affective potentialities of INFERNO in an interview with Vogue. They say INFERNO is 'a catwalk, an art exhibition, a runway, it's a really beautiful rave where you're going to meet really beautiful people from all walks of life: people who are really dressed to the extremes and people who are wearing hardly any clothes. It's a place without judgment where you can really let your hair down, and really have a good fucking time ${ }^{16}$.

12 Can we stay with that invitation a little longer? As I entered the ICA and sought out the other queers I knew, I remember sharing looks, glances, smiles, the feelings of desiring and of being desired. I lingered with a tall blond with a bandage over their nose - who I later found out would be performing that night. There is no way to tell a performer from an attendant by their dress, because everyone is dressed up and everyone is here to perform. I lingered with them at the turn of the space, both of us in lycra shorts and beat for some old gods, our queer ancestors who entered the space with us. We hug, kiss, let our hands and arms linger on each other's hips. We roll cigarettes and move into the deep exposing and endless swarm of bodies in the main room. The red lights gloam through smoke, as the decomposed acid house ricochets between us, reverberating (with) us. The socio-aesthetics of the night-where queer people turn looks and paint themselves to appear like they have gone through, or in fact come from the underworld - indexes an apocalypse. Different rave spaces cultivate their own aesthetics, and this is INFERNO's. The performances of becoming-with each other evacuated established normative modes of 'being human'. We were latex pups, and vampire doms, who danced with genderqueer witch subs, beautiful bedroom monsters, and cultural giants.

13 I had always read the apocalypse which INFERNO stages to be one in which there had been a mass failure of racist hetero-patriarchal capitalism. In this sense I experienced INFERNO as a rave for the end of normative society. It was a rave that intoned the death of the concept of Man and the arrival into space, matter, and imagination of more open possibilities for becoming-together. This failure resonates with Halberstam and Muñoz's visions for the queer potentials of failure as an art or as entangled with utopian futurities. Being en commun we could think of this assemblage of apocalyptic monster-becomings as a diffusion of the human body, a deconstruction of the normate body ${ }^{17}$ and the body normatively constructed by colonial and neo colonial discourses ${ }^{18}$.

14 In this way INFERNO functions as a speculative materialist space. For us, the body was unbounded from a 'singular self, in the sense that Julietta Singh uses to describe the 
body archive. In that, the rave allowed the concept of the body as a thing with limits, with boundaries, to fail. Our bodies became open attunements fleshed and enfleshed reiteratively. In an investigation of the body archive Singh goes on to note, as she quotes feminist philosopher Nancy Tuana, that there is a dissolution of,

'the boundaries between our flesh and the flesh of the world'. These feminist formulations of the body insist on our vital entanglements with the outside world, complicating any easy binary demarcations of 'inside' and 'outside'. For better and for worse, we are made up of an outside world which constitutes, nourishes, and poisons us in turns. This is not only a material problem for my body archive, but also an affective one. In the end, we are not bounded, contained subjects, but ones filled up with foreign feelings and vibes that linger and circulate in space, that enter us as we move through our lives. We likewise leave traces of ourselves and our own affective states (which are never really just our own) behind us when we go $^{19}$.

By attuning ourselves not only to the traces we leave but the vibes and feelings left behind we can re-figure our relationship to the events, states, memories, and ghostings from the past. The return or re-enactment of certain gestures, thoughts, and feelings becomes a re-attunement to queer sociality ${ }^{20}$.

At INFERNO this unbounding of the single self-body performs the end of heteronormative racist capitalism in two keys. The first is as a catastrophic materialist failure: the end of the structures, systems and discourses that bind, oppress, and extract. The second is as a conceptual category failure, the end of 'human' or of ' man $^{21}$ '. These failures are not causally related but entangled in a non-linear and discontinuous fashion $^{22}$. As in, it is not that INFERNO wants to perform the collapse of neo-colonial, neo-liberal capitalism and thus creates a failure in the concept of the human, but that both collapse and failure are refracted by the other and both the 'human' and racist capital have and continue to be deeply entangled, hard to separate ${ }^{23}$. In short, as the participants enact an apocalypse, as they dance through catastrophe, the feeling of INFERNO is that a queer utopia is arriving as an imperative state in the present, as a pose.

17 However, this is a utopic futurity rendered in the rave. The night still happens within an enclosure: the ICA. Additionally, this is a reading generated by my own partiality and positionality as a white queer, as in, a queer who has benefited from the racist and ableist structures of the neo-colonial present that the rave seeks to disrupt. So, in balance, I would note that my hopeful reading is also vulnerable to failure through its partiality. I am striving towards what Donna Haraway would term 'critical knowledges sustaining the possibilities of webs of connections called solidarity in politics and shared conversations in epistemology ${ }^{24}$. In that vein I want to note then that the enclosure of the ICA is not itself a realised utopic or fully anti-normative space. It still runs under the market, under the conditions of those violent hierarchical structures and power relations. It is still a space open to further anti-racist critique, queer, and crip interventions.

\section{Failing}

18 I want to move away from my embodied recollections towards the traces of many other bodies in the rave. To access the performances from that night I have used a video recording which I have saved on my phone. While this video does archive the live 
performance it also captures the feeling of being there with the performers and maintains some of the worldings I think we were suggesting. Moving from partiality towards a web of connections called solidarity I want to begin listening to the reverberations of the structural systems of oppression engaged with at the rave and the traces left behind from INFERNO ${ }^{25}$. As I note in another paper on the queer rave: Lauren Berlant and Michael Warner have already thought of the constellation of these innumerable queers in site-responsive live-art and sexual-play-focused situations. Thinking with them I try to attend to the ways in which multi-species assemblages cofunction at the rave, through queer worldings' becoming possible.

The queer world is a space of entrances, exits, unsystematized lines of acquaintance, projected horizons, typifying examples, alternate routes, blockages, incommensurate geographies. World making, as much in the mode of dirty talk as of print-mediated representation, is dispersed through incommensurate registers, by definition unrealizable as community or identity [...] Queer and other insurgents have long striven, often dangerously or scandalously, to cultivate what good folks used to call criminal intimacies. We have developed relations and narratives that are only recognized as intimate in queer culture [...] Queer culture has learned not only how to sexualize these and other relations, but also to use them as a context for witnessing intense and personal affect while elaborating a public world of belonging and transformation. [...] They are typical both of the inventiveness of queer world making and of the queer world's fragility ${ }^{26}$.

What the queer rave provides, in its ability to functionally disrupt the spaces in which ideas and concepts form, is a playground for new affinities and assemblage-play. But that space and the disorganization of time it proposes is fragile. Alternative futurities can falter, forcing us to crash land back into the present. And that temporal disorganization can leave people behind, being outside of or unable to participate in the throng of sweating, cruising bodies.

In the embodied queer understanding we gather from Love, Muñoz, and Halberstam, failure is something done, something felt, fantasised about or regretted. It is a feeling state which brings with it a particular understanding of time that refuses the genealogic temporalities of progress and the presuppositions of pseudo-biologic development models ${ }^{27}$. As we've seen, exploring this haptic time through performance is accomplished with ideas of repetition, glitching and exhaustion. It is generative in that it can conjure up, even if only for a moment, the potential for an alternative world. However, there is an attendant danger. In Alison Kafer's exploration of the intersections, material affinity networks, and coalitions between queer and disability studies, she writes about how we might develop a theory of failure in relation to other disabilities studies academics and practitioners. She references Merri Lisa Johnson, 'Bad Romance: A Crip Feminist Critique of Queer Failure' and S. Naomi Finkelstein's 2003 essay 'The Only Thing You Have to do is Live' to note that,

Finkelstein's rumination offers a caution to threads of queer theory that cast failure only as transgressive, electrifying, sexy. As Johnson notes, queer crip theory requires "a more precise typology of failure," one that can "acknowledge the pleasures of failure - embodied in choices to stand apart from social norms of gender, sexuality, reprocentricity, and romantic affiliation - and the distress of failures embodied in lives gone haywire, symptoms run rampant, personal lives devolving into uninhabitable havoc." How might queer approaches to failing at one's gender shift, for example, when disability is brought into the $\mathrm{mix}^{28}$ ?

21 Following this urgent provocation, queer performances can be understood as being situated in coalition with a call for a more precise typology of failure - that 
acknowledges both the pleasures and distresses, the entry ways and boundaries to access. Thus, failure must remain in dialogue with the socially constructed model of disability as it must too remain with the trouble posed by the demands of cisheteronormativity and capitalism. This is important in the context of the queer rave, as raves aren't always places of unbounded pleasure. Racism, ableism, and Empire can still be present, can still structure and invade the queer rave.

\section{Theseus on the Heap}

We squeeze through the door into a heaving room ${ }^{29}$. Barely making it in. There are two rostra set up, one in the center and another to the left in an alcove - bodies flood the space around them both. Three performers stand stock still on the left rostrum, naked, powdered white into statue-poses. The two behind flank one in the middle who stands slightly closer to the front-edge of the stage. They have rendered themselves somewhere between the gestures of an ancient Greek nude statue and a freeze frame of a vogue battle. The red club lights beam over their bodies and cast shadows into an audience of (intoxicated) heady queers. It has just crossed over into the early hours of Saturday morning. They wait. And we wait with them. The music has dimmed, the dancing stopped, and we breath into the rhythms of a new performance modality. When the time is right a multi-racial, genderqueer chorus in white latex, white cloth, move up from the crowd, forming a barrier along the front of the make-shift thrust stage. They hold phones, with pulsing white TV-static light, so that the screens face out towards the crowd: almost like an advance guard, almost like a row of columns. Then a voiceover begins. It describes a warn-torn mythic landscape littered with the heroes of ancient Greece: Theseus, Heracles, Achilles, Eurystheus. We hear of revenge, tragedy, and the bloodshot sun hanging low over a Temple of Hera. Something ancient has been set up in this rave for the end of humanity.

The (dis)embodied voice continues and the chorus turn and drip towards the ground. As they lower a single performer appears from behind them. Sue Gives a Fuck rises, as if from deep within the earth. The reveal has enough effect to generate cheers, ululations, that build in volume and frequency. Sue responds to this voiceover, as if it is emanating from her, and reverberating from the outside into her. Her pose shifts to meet the cheering crowd. Then the lighting turns from deep red to something else strangely familiar. This second colour, a deep gauzy saffron, had filled lungs and Instagram feeds months earlier at the Olafur Eliason show at the Tate - 'In Real Life' (Tate Modern, 2019-2020). The queer internet buzz, and the disorientating affect of that show returns here, as if we had descended back into Eliasson's tunnel, and these ancient queer mythological beings, had emerged out of that darkness with us into this setting. Time eddies, and inflects as Sue turns to gaze upon her new adorants. The chorus begin their performance ritual, passing a vase around their communal group. And Sue, edging towards each one, pours down into their open mouths, cool water. Technic electro gutters the room, a soft cry of appreciation. Then, Sue is gone. There is stillness and waiting, as we turn towards the statues who begin to move. The chorus spit the liquid from their mouths at these creaking hero/gods, before crawling off the make-shift platform. The middle performer, currently the sole standing naked artist, begins to crack their entire body against the space, in time to the music. They begin to isolate their hips, elbows, shoulders, neck, and ribs. It's as if the sound is coming from 
their body's articulated cracks and slaps, and is simultaneously reverberating against their flesh. The two performers behind this virtuosic system of gesture begin to rise. The haze of Eliason's tunnel and the suggested ecstasies of the performance bends memories against potential futurities. This kind of triad (theoretical, erotic, temporal) is oddly and somehow assuredly placed within the context of an ancient phantasm creaking to life. What are we supposed to make of this ancient Greek reference, this evocation of myth, heroism, and tragedy?

Images of 'Theseus on the Heap'

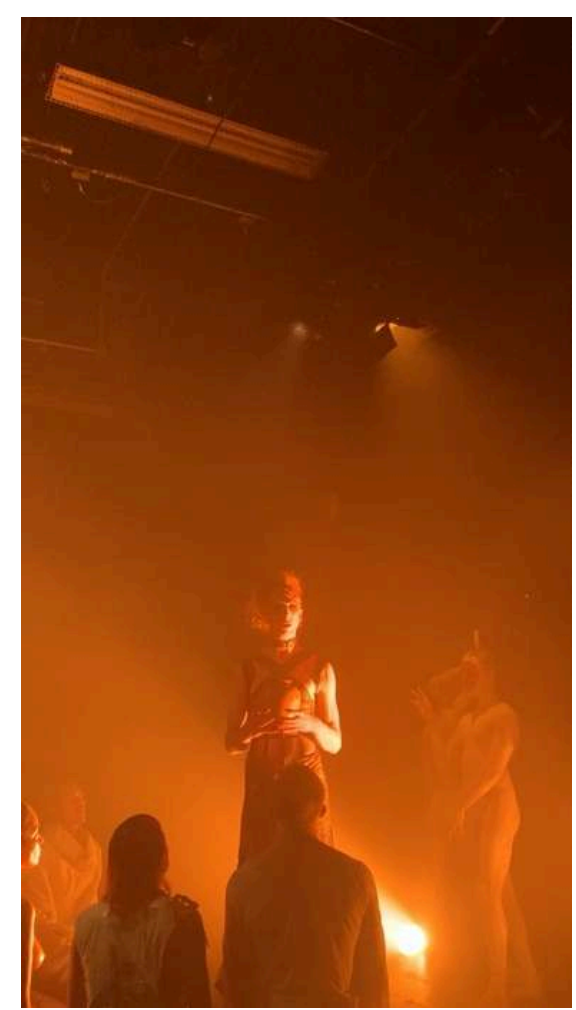



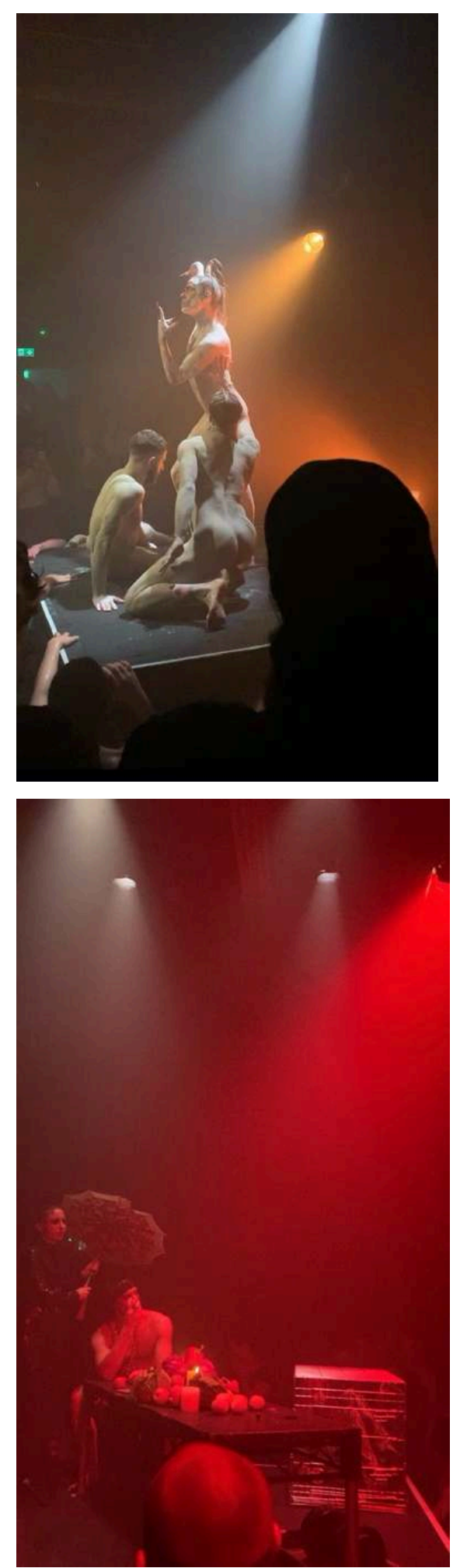

Screenshots from a video taken of the performance. Choreographed by Nick Finegan. Author's own

24 There is stillness again. Until, the other two dancers come forward. They take deep, thick, slow steps. They turn, and pause again, before gliding into honeyed poses. The music drops like the heat of a summer day breaking to rain. The bass and driving triplets cast the two attendant dancers' arms back over their heads in a deep back 
bend. Rising cheers meet the melting of the central figure, the treble comes in and the two attendant dancers mirror each other, framing the central hero/god. Their sharp elbows, and driving fists propel them through the space, down and back. Until, at the feet of the central dancer they inhale, inches away from one another, and finally make contact. Their hands trace each other's flesh, over lower backs, buttocks, thighs, shoulders until they find another constellation of poses. One dancer melts through a deep plie rising back up onto their right leg, their left raised slowly so that it levitates at ninety degrees to their torso. Their use of release and gravity allows them to, so tenderly, arrive at a stop-almost as if they are resting against the air which hangs between them and the central figure. As they hover the central figure reaches deep into their open mouth, pulling a key on a long chain from far inside their throat. The rhythm of the music starts to decompose as the deep red light floods the room again. The three figures stop still and turn to stare at a second platform across the other side of the room. Here we find Hercules. He is lifting weights, shaking a cage inside which another performer sits. Fruit is torn open against gnashing teeth. Eventually, our three dancers appear on this platform too. Demi-gods and goddesses arriving as if from Olympus above or from the soil of chthonic realm, from the inferno.

As Lewis Burton notes, 'the sound of INFERNO is very dark very industrial-lots of techno. Very hard dance trance style beats that overwhelms your body and you feel this shake through your core ${ }^{30}$. Here the dancers' reverberated with and alongside us in the space. And yet, here too the normative power structures of the neo-capitalist and settler colonial world re-emerged. In the moment where an ancient Greek mythic system begins to re-cohere the cages, chains, and modes of subjection and domination were played out on the stage. If the beginning of the performance and the rest of the night had been about raving against these modes of domination, here they were put into play.

Hercules/Theseus/Achilles/Eurystheus is fed an object too grainy to make out in the video I have. His body convulses and breaks, echoing the articulations of the first nude sculptural dancer. He is carried back across to Sue where the chorus re-emerge. And after a gesture from her they begin to perform a sparagmos. They tear into his flesh, miming the ripping, grabbing and throwing-out-of-the-space of a bacchic end. Here the violence of the beginning of the twenty-first century is recovered and played out on stage. Here too there is a materialisation of a different kind of diffused and unbounded body.

The sparagmos positioned our Heracles/Theseus/Achilles/Eurystheus as yet another Pentheus figure - the Greek ruler who denied Dionysus godhead in Euripides Bacchae and went up to mount Cithaeron in the guise of a bacchant to spy on the celebrants there. He was eventually brought back to the city of Thebes in pieces, his head clasped in his mother's hands. And those women were brutally punished for ever having questioned Dionysus' divinity. This tragedy has been played out before. Richard Schechner and Yael Faber both use Bacchae to set up durational participatory performances that in some way end up exploiting performers and audience members in attendance. Michael Grüber thought about deconstructing theatrical form with this play. Branden Jacobs-Jenkins and Caryl Churchill have thought about, with, and against forms of racist heteropatriarchal oppression with Bacchae too. The danger here in the appearance of this maenadic murder is that we lean on the figuration of Pentheus. This can be avoided I believe, if we think less about the act of Pentheus being torn apart and 
more about a collection of queers already dematerialising, the chorus or engine of 'Theseus on the Heap'.

\section{Chorus}

What figure could help us engage with the complexities of refusal and resistance that play out here and, especially, aid us in thinking about failure as a performance modality at the queer rave. Some of this thinking has already been done. Saidiya Hartman, a theorist and writer in African American and American literature, cultural history, slavery, law and literature, and performance studies, has investigated these tangles and knots throughout her career. Towards the very end of her recent radical scholarship on the lives of young black women in the early twentieth century, Wayward Live, Beautiful Experiments (2019), Hartman creates an affective and discursive space for thinking and feeling with the chorus. This is a chorus of 'Muses, drudges, washerwomen, whores, house workers, factory girls, waitresses, and aspiring but never-to-be stars ${ }^{31}$. It is a collection of those dispossessed, violently captured, extracted, abused, or dehumanised. It is a space for listening and holding onto the alternative futurities hoped for, awaited, and denied to marginalised, enslaved, indentured, and incarcerated folks.

Hartman reflects on the effort of continuing to believe in these alternative worldings in the face of suffering caused by the 'Anthropocene', by racism, global capitalism, police brutality and state killing ${ }^{32}$. She notes,

The chorus bears all of it for us. The Greek etymology of the word chorus refers to dance within an enclosure. What better articulates the long history of struggle, the ceaseless practice of black radicalism and refusal, the tumult and upheaval of open rebellion than the acts of collaboration and improvisation that unfold within the space of enclosure? The chorus is the vehicle for another kind of story, not of the great man or the tragic hero, but one in which all modalities play a part, where the headless group incites change, where mutual aid provides the resource for collective action, not leader and mass, where the untranslatable songs and seeming nonsense make good the promise of revolution. The chorus propels transformation. It is an incubator of possibility, an assembly sustaining dreams of the otherwise ${ }^{33}$.

Bringing in and thinking with Hartman here, at the end, makes space for and emphasises the work and labour of Black feminists in coalition with queer and crip thinking. Hartman is enacting, along with Campt and Brand, not only a way of thinking about or maintaining 'hope' for alternative worldings but instead making demands for those alternatives to be performed in the present through systems of mutual aid, and headless group action. It allows us to take in the seeming nonsense and untranslatable songs of the queer rave and to think about the methods by which we could make good on the promise of revolution these uses of failure, as modality, in performance trace.

Within INFERNO's queer modulations of the ICA 'Theseus on the Heap' made space for this chorus. As I argued, two of the failures INFERNO performed were, one: a failure of the structures of neo-colonialism, of the Classical, and two: the failure of the category of human. In the performance this energy doubles back on itself. As those structures of capture and harm emerge in the space. This is a moment where the queer futurity, indexed by the apocalyptic looks the audience were turning, feels particularly fragile. The proximity of this crisis to a post-apocalyptic future wherein the tools of coloniality could re-emerge threatens the stability of the raves futurity almost forcing us to crash 
land back into the pain of the racist neo-colonialist present that we haven't fully left. Here the distress of failure should be attended to along the intersectional lines laid out by Kafer. Yet at the same time, the performance and the rave allowed failure to be taken up as a modality for thinking and feeling elsewhere and otherwise through the figure of the chorus. Their presence in 'Theseus on a Heap' foregrounds the energies of ritual care, rage, and ecstatic celebration by which the performance began, they destroyed the show's composite 'great man or tragic hero figure', and they are the way in which the performance melted away, dissipating back into the crowd. The chorus called us to join them to try and heal from the pain and suffering of the past and present, to hold that pain together, and they asked us to listen to their cacophony telling us we need to move onwards, in wayward lines of flight.

This generative and anti-generative relationship with failure as a concept, embedded within INFERNO allows us to encounter a queer relationship to both ancient Greece and to potential futures. In my analysis of this work I hope to have shown that by performing 'Theseus on the Heap' within the ICA the performer-artists rendered a deconstructed tragedy, a form that has sadly already become a reconstruction of classical ideals and a way of recuperating an exceptionalised ancient Greek past. But in this queer version of that established mode, the artists generated a space for questioning the usefulness and coloniality of the Greek tragic hero. I proposed that even the emergence of that tragic hero composite: Theseus/Heracles/Achilles/ Eurystheus/Pentheus was to be diminished further still within the wider enclosure of INFERNO through the function of the chorus and, specifically, Hartman's theorisation of it. This emphasis on the chorus who interfaced with the audience-performers within INFERNO, wherein failure was performed as a modality, drove on the belief that another world is possible. In this reflection then the chorus encourages us to keep asking those questions I began this paper with even if we are worried the process of answering them will itself involve failure. So I will ask them here again: what if we did 'burn it all down', what world would be possible after the end of man, and how can we as queers celebrate each other, our practices of seeing, making, and emerging together ${ }^{34}$ ?

In this paper I have attempted to think about an alternative to overturning success and failure and have tried to recall the collective enfleshings and worldings of the queer rave. Attuning to the body archive and the assemblage of traces that gather around INFERNO has uncovered the many potential erotic, political and care driven modalities for becoming-together that were amplified that night. I hope it has echoed many other similar nights. If it did, and has allowed us to see and be with the performed failure of the human as a category-and the apocalyptic failure of global capitalism and the concept of man-then, I hope it allows for further opportunities to be in the chorus' circle, to sustain and enact their dreams of otherwise. 


\section{BIBLIOGRAPHY}

AMIN, K., Disturbing Attachments: Genet, Modern Pederasty, and Queer History, Durham, London, Duke University Press, 2017.

BERLANT, L., and WARNER, M., 'Sex in Public', in Critical Inquiry 24.2, 'Intimacy', Winter 1998, p. 547-566.

BELL, M., “'Hold Me, Spit on Me, Cover Me in Care": Daphnis and Chloe at a Rave Last Summer', in Love Spells \& Rituals for Another World, L., MARKAKI, and C. HARRIS (eds.), Independent Publishing Network, 2020.

BRAND, D., A Map to the Door of No Return: Notes to Belonging, Vintage Canada, 2001.

BRAND, D., 'What we saw. What we made. When we emerge', in Kitty Lundy Memorial Lecture, [en ligne], York University, 2021. URL: https://www.youtube.com/watch?v=P9rrU-t1Ncw [Site consulté le 15/03/21].

CAMPT, T. M., Listening to Images, Durham and London, Duke University Press, 2017.

DELANEY, J., Video, short doc for British Vogue's 'A Celebration of Pride' series, [en ligne], 2020. URL: https://www.promonews.tv/videos/2020/07/06/alex-johnston-rhythm-resistance-josephdelaney/65524 [Site consulté le 11/03/21].

EDELMAN, L., No Future: Queer Theory and the Death Drive, Durham and London, Duke University Press, 2004.

ELLIS, N., 'Trace a Vanishing, or Queer Performance Study' in The Cambridge Companion to Queer Studies, [en ligne], S. B., SOMERVILLE (ed.), 2020, p. 156-171. URL: https://doi.org/ $10.1017 / 9781108699396$ [Site consulté le 11/03/21].

FINKELSTEIN, S. N., 'The Only Thing You Have to Do Is Live', in GLQ:A Journal of Lesbian and Gay Studies, 9:1-2, 2003, p. 307-319.

FOUCAULT, M., 'Technologies of the Self', Lectures at University of Vermont Oct. 1982, in Technologies of the Self, USA, University of Massachusetts Press, 1988, p. 16-49.

HARRAWAY, D., 'Situated Knowledges: The Science Question in Feminism and the Privilege of Partial Perspective', in Feminist Studies, [en ligne], 14:3, 1988, p. 575-599. URL: https://doi.org/ 10.2307/3178066 [Site consulté le 11/03/21].

HARTMAN, S., Wayward Lives, Beautiful Experiments: Intimate Histories of Riotous Black Girls, Troublesome Women and Queer Radicals, London and New York, Serpent's Tail, 2019.

HASSELSWERT, E., "Sappho's Body / Towards a Deep Lez Philology”, in Queer and the Classical: Futures and Potentialities, [en ligne], Seminar Series, 2020. URL: https://queerandtheclassical.org/ seminar-series-2020 [Site consulté le 15/03/21].

HEDVA, J., 'Sick Woman Theory', in Mask, [en ligne], 'The Not Again Issue', 16/01/2016. URL: http://www.maskmagazine.com/not-again/struggle/sick-woman-theory [Site consulté le 15/03/21].

JOHNSON, M. L., ‘Bad Romance: A Crip Feminist Critique of Queer Failure', in Hypatia 30, 2015, p. 251-267. 
KAFER, A., 'Queer Disability Studies', in The Cambridge Companion to Queer Studies, [en ligne], S. B. Somerville (ed.), 2020, p. 93-107. URL: https://doi.org/10.1017/9781108699396 [Site consulté le $15 / 03 / 21]$.

LOVE, H., Feeling Backward: Loss and the Politics of Queer History, Cambridge and London, Harvard University Press, 2007.

MUNOZ, J. E., Disidentifications, Minneapolis, London, University of Minnesota Press, 1999.

MUNOZ, J. E., Cruising Utopia: The Then and There of Queer Futurity (10th Anniversary ed.), New York, NY, New York University Press, 2009.

MUNOZ, J. E., The Sense of Brown, Durham and London, Duke University Press, 2020.

NYONG'O, T., Afro-Fabulations: The Queer Drama of Black Life, New York, NY, New York University Press, 2018.

PAPANIKOLAOU, D., 'The pensive spectator, the possessive reader and the archive of queer feelings: A reading of Constantine Giannaris's Trojans', Journal of Greek Media \& Culture, [en ligne], 1:2, 2015, p. 279-297. URL: https://doi.org/10.1386/jgmc.1.2.279_1 [Site consulté le 15/03/21].

SHARPE, C., In the Wake: On Blackness and Being, Durham and London, Duke University Press, 2016.

SINGH, J., No Archive Will Restore You, [en ligne], Ecologies Books/Immediations, Punctum, 2018. URL: https://punctumbooks.com/titles/no-archive-will-restore-you/ [Site consulté le 15/03/21].

SCHNEIDER, R., Performing Remains: Art and War in Times of Theatrical Reenactment, London and New York, Routledge, 2011.

SCHNEIDER, R., 'That the Past May Yet Have Another Future: Gesture in the Times of Hands Up', in Theatre Journal, 70:3, 2018, p. 285-306

UMACHANDRAN, M., and WARD, M., 'The Case for Critical Ancient World Studies', [en ligne], a Call, 2020. URL: https://www.fasticongressuum.com/single-post/2020/02/06/call-28022020-thecase-for-critical-ancient-world-studies-oxford-england, [Site consulté le 15/03/21].

WARD, M., 'Cripping Ancestorship for Queer Time: On Refusing the Genealogy of the Classical', presented at Queer and The Classical: Critical Futures, Critical Feelings, [en ligne], conference, 2021. URL: https://queerandtheclassical.org/conference-program [Site consulté le 15/03/21].

WEHELIYE, A. G., Habeas Viscus: Racializing Assemblages, Biopolitics, and Black Feminist Theories of the Human, [en ligne], Duke University Press, 2014. URL: https://ezproxy-prd.bodleian.ox.ac.uk: 2102/10.1215/9780822376491 [Site consulté le 15/03/21].

WYNTER, S., 'Unsettling the Coloniality of Being/Power/Truth/Freedom: Towards the Human, After Man, Its Overrepresentation-An Argument', in The New Centennial Review, [en ligne], 3:3, Michigan State University Press, 2003, p. 257-337. URL: https://doi.org/10.1353/ncr.2004.0015 [Site consulté le 15/03/21].

WYNTER, S., and MCKITTRICK K., 'Unparalleled Catastrophe for Our Species?: Or, to Give Humanness a Different Future: Conversations' in Sylvia Wynter: On Being Human as Praxis, K. MCKITTRICK (ed.), Durham and London, Duke University Press, 2015, p. 10-89.

YUSOFF, K., A Billion Black Anthropocenes or None, Minneapolis, University of Minnesota Press, 2018. 


\section{NOTES}

1. See J. E., Munoz, Disidentifications, Minneapolis, London, University of Minnesota Press, 1999; J. E., Munoz, Cruising Utopia: The Then and There of Queer Futurity (10 ${ }^{\text {th }}$ Anniversary ed.), New York, NY, New York University Press, 2009; J. E., Munoz, The Sense of Brown, Durham and London, Duke University Press, 2020; N., Ellis, 'Trace a Vanishing, or Queer Performance Study' in The Cambridge Companion to Queer Studies, [en ligne], S. B., Somerville (ed.), 2020, p. 156-171. URL: https://doi.org/ 10.1017/9781108699396 [Site consulté le 11/03/21]; A., Kafer, 'Queer Disability Studies', in The Cambridge Companion to Queer Studies, [en ligne], S. B. Somerville (ed.), 2020, p. 93-107. URL: https://doi.org/10.1017/9781108699396 [Site consulté le 15/03/21]; T., Nyong'o, Afro-Fabulations: The Queer Drama of Black Life, New York, NY, New York University Press, 2018.

2. D., Brand, 'What we saw. What we made. When we emerge', in Kitty Lundy Memorial Lecture, [en ligne], York University, 2021. URL: https://www.youtube.com/watch? $\mathrm{v}=$ P9rrU-t1Ncw [Site consulté le 15/03/21].

3. Still listed online as 'Enter the Temple of Hera', a working name, the pieces final title was given as 'Theseus on the Heap'.

4. The performers who gave themselves over to 'Theseus on the Heap' and to INFERNO that night are as follows: Sue Gives a Fuck, Rezm Morah, Chester Hayes, Francesco Miggliaccio, Nick Finegan, Rudi MC, Radam Ridwan, Joey Davidson, Luly Love, Magnus McCullagh, Gabriella Peach Faparini, and Valeria McLaren.

5. For retheorising the 'human' see A.G., Weheliye, Habeas Viscus: Racializing Assemblages, Biopolitics, and Black Feminist Theories of the Human, [en ligne], Duke University Press, 2014. URL: https://ezproxy-prd.bodleian.ox.ac.uk: 2102/10.1215/9780822376491 [Site consulté le 15/03/21]; S., Wynter, 'Unsettling the Coloniality of Being/Power/Truth/Freedom: Towards the Human, After Man, Its Overrepresentation-An Argument', in The New Centennial Review, [en ligne], 3:3, Michigan State University Press, 2003, p. 257-337. URL: https://doi.org/10.1353/ncr. 2004.0015 [Site consulté le 15/03/21]; K., Yusoff, A Billion Black Anthropocenes or None, Minneapolis, University of Minnesota Press, 2018.

6. Jack Halberstam quoted by D., Papanikolaou, 'The pensive spectator, the possessive reader and the archive of queer feelings: A reading of Constantine Giannaris's Trojans', Journal of Greek Media \& Culture, [en ligne], 1:2, 2015, p. 293. URL: https://doi.org/ 10.1386/jgmc.1.2.279_1 [Site consulté le 15/03/21].

7. J. E., Munoz, Disidentifications, Minneapolis, London, University of Minnesota Press, 1999; J. E., Munoz, Cruising Utopia: The Then and There of Queer Futurity (10 ${ }^{\text {th }}$ Anniversary ed.), New York, NY, New York University Press, 2009.

8. Here I am picking up S. Hartman and playing with M. Foucault's notion of the technologies of the self: S., Hartman, Wayward Lives, Beautiful Experiments: Intimate Histories of Riotous Black Girls, Troublesome Women and Queer Radicals, London and New York, Serpent's Tail, 2019; M., Foucault, 'Technologies of the Self', Lectures at University of Vermont Oct. 1982, in Technologies of the Self, USA, University of Massachusetts Press, 1988, p. 16-49.

9. See L., Edelman, No Future: Queer Theory and the Death Drive, Durham and London, Duke University Press, 2004. 
10. For bad feelings see H., Love, Feeling Backward: Loss and the Politics of Queer History, Cambridge and London, Harvard University Press, 2007, p. 12 and 159.

11. See D., Brand, A Map to the Door of No Return: Notes to Belonging, Vintage Canada, 2001; T. M., Campt, Listening to Images, Durham and London, Duke University Press, 2017; S., Hartman, op. cit.; A., Kafer, op. cit.; J., Hedva, 'Sick Woman Theory', in Mask, [en ligne], 'The Not Again Issue', 16/01/2016. URL: http://www.maskmagazine.com/not-again/ struggle/sick-woman-theory [Site consulté le 15/03/21].

12. T. M., Campt, op. cit.

13. M., Umachandran, and M., Ward, 'The Case for Critical Ancient World Studies', [en ligne], a Call, 2020. URL: https://www.fasticongressuum.com/single-post/2020/02/06/ call-28022020-the-case-for-critical-ancient-world-studies-oxford-england, [Site consulté le 15/03/21].

14. See J., Singh, No Archive Will Restore You, [en ligne], Ecologies Books/Immediations, Punctum, 2018. URL: https://punctumbooks.com/titles/no-archive-will-restore-you/ [Site consulté le 15/03/21]; T. M., Campt, op. cit.; R., Schneider, Performing Remains: Art and War in Times of Theatrical Reenactment, London and New York, Routledge, 2011.

15. Taken from INFERNO's webpage: https://www.infernolondon.com/ [Site consulté le 15/03/21].

16. J., Delaney, Video, short doc for British Vogue's 'A Celebration of Pride' series, [en ligne], 2020. URL: https://www.promonews.tv/videos/2020/07/06/alex-johnston-rhythmresistance-joseph-delaney/65524 [Site consulté le 11/03/21].

17. A., Kafer, op. cit.

18. J., Singh, op. cit.

19. Ibid. p. 30.

20. T. M., Campt, op. cit., p. 33.

21. S., Wynter, op. cit., p. 260; K., Yusoff, op. cit., p. 18.

22. See T. M., Campt, op. cit.; S., Wynter, op. cit.; K., Yusoff, op. cit.; C., Sharpe, In the Wake: On Blackness and Being, Durham et Londres, Duke University Press, 2016; S., Wynter, and K., Mckittrick, 'Unparalleled Catastrophe for Our Species?: Or, to Give Humanness a Different Future: Conversations' in Sylvia Wynter: On Being Human as Praxis, K. Mckittrick (ed.), Durham and London, Duke University Press, 2015, p. 10-89.

23. Ibid.

24. D., Harraway, 'Situated Knowledges: The Science Question in Feminism and the Privilege of Partial Perspective', in Feminist Studies, [en ligne], 14:3, 1988, p. 584. URL: https://doi.org/10.2307/3178066 [Site consulté le 11/03/21]; E., Hasselswert, "Sappho's Body / Towards a Deep Lez Philology", in Queer and the Classical: Futures and Potentialities, [en ligne], Seminar Series, 2020. URL: https://queerandtheclassical.org/seminarseries-2020 [Site consulté le 15/03/21].

25. N., Ellis, op. cit.

26. M., Bell, "'Hold Me, Spit on Me, Cover Me in Care": Daphnis and Chloe at a Rave Last Summer', in Love Spells \& Rituals for Another World, L., Markaki, and C., Harris (eds.), Independent Publishing Network, 2020 referencing: L., Berlant, and M., Warner, 'Sex in Public', in Critical Inquiry, 24.2, 'Intimacy', Winter 1998, p. 558; emphasis added.

27. M., Ward, 'Cripping Ancestorship for Queer Time: On Refusing the Genealogy of the Classical', presented at Queer and The Classical: Critical Futures, Critical Feelings, [en ligne], 
conference, 2021. URL: https://queerandtheclassical.org/conference-program [Site consulté le 15/03/21].

28. A., Kafer, op. cit., p. 102; emphasis in original.

29. You can access pictures of this event on the website: https://www.nickfinegan.com/ theseusontheheap

30. J., Delaney, Video, short doc for British Vogue's 'A Celebration of Pride' series, [en ligne], 2020. URL: https://www.promonews.tv/videos/2020/07/06/alex-johnston-rhythm-resistance-josephdelaney/65524 [Site consulté le 11/03/21].

31. S. Hartman, op. cit., p. 475.

32. Ibid.

33. Ibid., p. 478.

34. D., Brand, 'What we saw. What we made. When we emerge', in Kitty Lundy Memorial Lecture, [en ligne], York University, 2021. URL: https://www.youtube.com/watch?v=P9rrU-t1Ncw [Site consulté le 15/03/21].

\section{ABSTRACTS}

Queer lives are in constant conversation with failure. But what use is this to queer folk? This paper considers the queer performance rave INFERNO's takeover of the Institute of Contemporary Art in London. In an examination of the rave's serendipitous network of deep affective relations, gestures, and affordances I articulate how failure functions within such a space. Moving past binary orientations of failure against or as a preference to success I examine Nick Finegan's 'Theseus on the Heap' (2019) - a hellish collage of ancient Greek myth and tragedy. I put forward the following thesis. By performing failure as a modality, the performers and rave participants explored a tension between the failure of and their re-emergance. By cleaving to these moments from the rave I hope this paper offers some lines of flight away from normate models of success-failure but also encourages a return to the ephemera of queer performance and live art in these times of pandemic and catastrophe.

\section{INDEX}

Mots-clés: Performance art, queer studies, practice as research, myth, apocalypse, Institute of Contemporary Art, commonality, community, failure, body archive

\section{AUTHOR}

\section{MARCUS BELL}

Marcus Bell is a Doctoral Candidate working on a project titled 'Choreographing Tragedy' at Oxford University. They are a co-convener of Queer and the Classical network which organised a seminar series, Fall 2020, and conference, 'Queer and the Classical: Critical Futures, Critical Feelings' Spring 2021. [https://queerandtheclassical.org] He is an REF evaluator for Classics Faculty at Oxford and Associate Lecturer in Theatre and Performance at Goldsmiths University. 
Marcus also works with ByJove Theatre company as an artistic associate and as a dance-artist with Thomas Page Dances, a company based between London and Oxford. 